4. Watson WA, Litovitz TL, Rodgers GC Jr, et al. 2002 Annual report of the American Association of Poison Control Centers Toxic Exposure Surveillance System. Am J Emerg Med. 2003;21(5):353-421. doi:10.1016/S0735-6757(03)00088-3.

5. Dunkley EJ, Isbister GK, Sibbritt D, Dawson AH, Whyte IM. The Hunter serotonin toxicity criteria: simple and accurate diagnostic decision rules for serotonin toxicity. QJM. 2003;96(9):635-642. doi:10.1093/qjmed/hcg109.

6. Boyer EW. Serotonin syndrome (serotonin toxicity). In Post TW, ed. UpToDate. Waltham, MA: UpToDate Inc., 2017. https://www.upto date.com/contents/serotonin-syndrome-serotonin-toxicity. Accessed July 25, 2017.

7. Ables AZ, Nagubilli R. Prevention, diagnosis, and management of serotonin syndrome. Am Fam Physician. 2010;81(9):1139-1142. http:// www.aafp.org/afp/2010/0501/p1139.html.

8. Graudins A, Stearman A, Chan B. Treatment of the serotonin syndrome with cyproheptadine. J Emerg Med. 1998;16(4):615-619. doi:10.1016/ S0736-4679(98)00057-2.
9. Lockwood AH. Blood ammonia levels and hepatic encephalopathy. Metab Brain Dis. 2004;19(3-4):345-349. doi:10.1023/B:MEBR.0000043980. 74574.eb.

10. Qureshi MO, Khokhar N, Shafqat F. Ammonia levels and the severity of hepatic encephalopathy. J Coll Physicians Surg Pak. 2014;24 (3):160-163.

11. Patel DD, Galarneau D. Serotonin syndrome with fluoxetine: two case reports. Ochsner J. 2016;16(4):554-557.

12. Keegan MT, Brown DR, Rabinstein AA. Serotonin syndrome from the interaction of cyclobenzaprine with other serotonergic drugs. Anesth Analg. 2006;103(6):1466-1468. doi:10.1213/01.ane.0000247699.81580.eb.

13. Bostankolu G, Ayhan Y, Cuhadaroglu F, Yazıcı MK. Serotonin syndrome with a combination of aripiprazole and fluoxetine: a case report. Ther Adv Psychopharmacol. 2015;5(2):138-140. doi:10.1177/ 2045125314561467.

14. Lappin RI, Auchincloss EL. Treatment of serotonin syndrome with cyproheptadine. N Engl J Med. 1994;331(15):1021-1022. doi:10.1056/ NEJM199410133311514.

\title{
Reader comments
}

Dr. Roberts,

Ireceived the copies of Baylor University Medical Center Proceedings from Tom Gore that you sent to him for me. I thank you very much. Also, thank you for publishing his review in the Proceedings. ${ }^{1}$ I hope that it may stimulate some physicians to become a little more politically involved. While medicine is and always has been my first love, I found politics to be interesting and challenging. The decisions made there have a great deal to do with how we deliver care. Thanks again and my very best regards.

\section{J. Roy Rowland, MD} Dublin, Georgia

1. Gore TB. Review: House Call: A Doctor's Time in Medicine and Government. Proc (Bayl Univ Med Cent). 2017;30:480. 